\title{
Growth and Structural Changes in the South Asian Economies of India, Nepal and Sri Lanka
}

\author{
- M. K. Agarwal ${ }^{1}$ and Ritika ${ }^{2}$
}

\begin{abstract}
South Asian region is characterized by developing economies with varying degrees of socio- economic development. These economies find low position in terms of human development at the global level. The South Asian economies are now being looked upon with high growth potentials. India is emerging as one of the fastest growing economy in the world and other economies are also showing better growth momentum. Sri Lanka has been especially showing better growth realization for the last one decade. But with regard to Nepal, growth momentum now seems to be getting weakened after showing better prospects earlier.
\end{abstract}

Economic growth and structural changes generally go together in developing economies. This helps in realignment of sectoral behavior and productivity. We examine these issues in this paper. Moreover, we analyze growth trend in the South Asian economies of India, Nepal and Sri Lanka. Besides, we compare the structural changes in the three economies with the help of an index (NAV) along with the growth pattern. The study covers different periods for these economies while using secondary data. Trend growth rate, acceleration test and index of structural change (NAV) are used for analysis. These analyses suggest varying levels of growth performances in the three economies. However, relationship between growth rates and structural transformations does not get statistical support in any of the economies.

Key words: growth, index, acceleration, structural change and regression estimates.

\section{Introduction}

At a time when the world economy is undergoing transformation in terms of the sources of growth, the focus is shifting towards the South Asian economy led by India. Indian economy has emerged as one of the fastest growing economies around the world and recently there is the Indian economy seems to have overtaken the fastest growing Chinese economy. In this context it becomes important to understand the growth of the Indian economy and other South Asian economies. In this paper we shall be taking up the economies of India, Sri Lanka and Nepal to

1 Professor, Department of Economics, University of Lucknow, Lucknow 226007 (India) mk.agarwal.lu@ gmail.com

2 Ph.D. student, Department of Economics, University of Lucknow, Lucknow 226007 (India) ritika. gupta67@gmail.com 
understand their growth and structural transformation. While Nepal is located north of India and is characterized as the Himalayan Kingdom, Sri Lanka is located in the south and is characterized as the pearl of the Indian Ocean. The three countries have been making efforts to grow and make forward movement. Therefore, in this paper, our efforts would be to understand the growth pattern and sectoral behavior in the three South Asian economies. Besides, we plan to understand the structural transformation in these three economies and its relation with the economic growth over a period of time. As these economies are at varying levels of economic development, analysis of structural transformation and sectoral relations along with the sectoral growth analysis form the core of this paper.

Economic growth and economic transformation have been the major developmental debate during the early era of economic development (Colin Clark, 1940; Chenery and Taylor, 1968; Rostow,1960; Lewis, 1954; Ranis and Fei, 1961, etc). To accelerate the process of economic growth in a sustained manner has become the most important policy issue in contemporary scenario. There are many studies which find out that acceleration in economic growth is due to their structural transformation (Nayyar 2006; Wallack 2003; Balakrishanan 2007). According to the United Nations surveys (2006), an examination of pattern of structural change over the past decades indicate that the fast growing developing economies are clearly characterized by dynamic transformations.

Kaur (2007) supports this phenomena and states that more comprehensive reforms are followed since 1991 and it helps to provide a significant step-up to growth rate in the Indian economy. By analyzing the trend growth rates during the pre-1991 reforms and the post-1991 reform periods, it is clearly established that the trend growth rates of the two periods are structurally different in India. Herath (2011) proves a clear change of economic growth in Sri Lanka before and after trade liberalization. Agarwal and Upadhyay (2006) have shown better growth and structural changes in the Nepalese economy during the 1990s. After liberalization, the country demonstrates acceleration in economic growth. Studies of break years of India's growth acceleration also help to analyze drivers of growth, including various aspects of structural change. In particular, analysis such as Wallack (2003) makes an attempt to econometrically determine the turning period 1992 on which growth rates of trade, transport, storage and communication sectors are shifted significantly. So, according to the given studies it is clearly shown that there is a relationship between growth rate and structural change. Nagaraj (2003) also examines the behavior of industrial sector. He finds industrial upturn in the 1980s which is more significant rather than the 1990s reforms in India. Several authors state that developing economies' growth acceleration benefited from a reallocation of labors from lower productivity sector to higher productivity sector (Kaldor, 1957; Lewis, 1954).

\section{Some Background Characteristics of India, Sri Lanka and Nepal}

South Asia is a group of eight countries which are not developed economies. Some are developing at faster pace while others are making slow growth and development. Before we could attempt to analyze the growth and structural changes in these three South Asian countries, we may ponder over some basic demographic and human development issues. Table-1 shows that India is the most populous country in the group with around 1.24 billion population. Globally, India ranks 
next to China in terms of population size. Nepal has only 31 million population which is much less compared to India. However, Nepal's population size is higher than the population of Sri Lanka (21.9 million) in 2014. Growth rate of the population is diminishing even in South Asian countries where Nepal still has very high growth rate (1.82 percent) unlike Sri Lanka that has almost half the growth rate of Nepal. In terms of the birth rate and death rate, all the three countries seem to be moving at higher stage of demographic transition where Nepal seems to be the least advanced among the three countries and Sri Lanka is the most advanced. Other demographic indicators suggest that Sri Lanka is far ahead of the two in terms of infant mortality rate, life expectancy, literacy rate as well as maternal mortality rate. On the other hand, Nepal has the poorest scenario. Therefore, Nepal has to make much more efforts to speed up its demographic transition and improve various demographic indicators of development.

Table-1: Demographic Profile

\begin{tabular}{|c|c|c|c|}
\hline Indicators & India & Nepal & Sri Lanka \\
\hline $\begin{array}{l}\text { Population } \\
(2014)\end{array}$ & 1,236 million & 31.0 million & 21.9 million \\
\hline $\begin{array}{l}\text { Population growth rate } \\
(2014)\end{array}$ & 1.25 percent & 1.82 percent & 0.86 percent \\
\hline $\begin{array}{l}\text { Birth rate } \\
\text { (2014) (Per } 1000 \text { pop.) }\end{array}$ & 19.89 & 21.07 & 16.24 \\
\hline $\begin{array}{l}\text { Death rate } \\
\text { (2014) (Per } 1000 \text { pop.) }\end{array}$ & 7.35 & 6.62 & 6.06 \\
\hline $\begin{array}{l}\text { Infant mortality rate } \\
(2014) \\
\text { (Per } 1000 \text { live births) }\end{array}$ & $\begin{array}{l}\text { Total: } 43.19 \\
\text { Male: } 41.9 \\
\text { Female: } 44.63\end{array}$ & $\begin{array}{l}\text { Total: } 40.43 \\
\text { Male: } 40.5 \\
\text { Female: } 40.35\end{array}$ & $\begin{array}{l}\text { Total: } 9.02 \\
\text { Male: } 9.98 \\
\text { Female: } 8.02\end{array}$ \\
\hline $\begin{array}{l}\text { Life expectancy at birth } \\
\text { In years } \\
(2014)\end{array}$ & $\begin{array}{l}\text { Total: } 67.8 \\
\text { Male: } 66.68 \\
\text { Female: } 69.06\end{array}$ & $\begin{array}{l}\text { Total: } 67.19 \\
\text { Male: } 65.88 \\
\text { Female: } 68.56\end{array}$ & $\begin{array}{l}\text { Total: } 76.35 \\
\text { Male: } 72.85 \\
\text { Female: } 79.99\end{array}$ \\
\hline $\begin{array}{l}\text { Total fertility rate } \\
\text { (2014) }\end{array}$ & 2.51 & 2.3 & 2.13 \\
\hline $\begin{array}{l}\text { Literacy rate } \\
\text { (Percent) }\end{array}$ & $\begin{array}{l}\text { Total: } 62.8 \\
\text { Male: } 75.2 \\
\text { Female: } 50.8 \\
(2006)\end{array}$ & $\begin{array}{l}\text { Total: } 57.4 \\
\text { Male: } 71.1 \\
\text { Female: } 46.7 \\
(2011)\end{array}$ & $\begin{array}{l}\text { Total: } 95.6 \\
\text { Male: } 96.8 \\
\text { Female: } 94.6 \\
\text { (2012) }\end{array}$ \\
\hline $\begin{array}{l}\text { Maternal mortality rate } \\
(2010)\end{array}$ & $\begin{array}{l}200 \text { deaths } \\
/ 100,000 \text { live } \\
\text { births }\end{array}$ & $\begin{array}{l}170 \text { deaths / } \\
100,000 \text { live births }\end{array}$ & $\begin{array}{l}35 \text { deaths } / 100,000 \\
\text { live births }\end{array}$ \\
\hline
\end{tabular}

Source: http://www.indexmundi.com/factbook/compare/india.sri-lanka

http://www.indexmundi.com/factbook/compare/india.nepal 
We may also look at the human development scenario in the three nations of the South Asia, viz. India, Sri Lanka and Nepal as reflected in Table-2. Of the three countries, Sri Lanka is having the best international status as it ranks around 73 among the nations of the world in 2014 whereas the other two countries rank much lower at 130 (India) and 145 (Nepal). Thus, in terms of the human development index (HDI) ranking, Nepal is not far behind India although the latter has been experiencing much faster economic growth rates. Nepal has made much faster progress in terms of the HDI during 1980 to 2014 as the value of the HDI has increased from 0.286 to 0.548 and it is almost doubled during the period of almost 35 years. However, it is not increased at this fast pace in India as it has increased from 0.369 to 0.609 in terms of value. As a result, the gap between India and Nepal has been reduced although India has marginally improved its ranking among the nations. The HDI value of Sri Lanka remains much higher at 0.757. Still, the South Asian countries need to do a lot for improvements in terms of HDI.

Table-2: Human Development Index in India, Sri Lanka and Nepal

\begin{tabular}{|l|r|r|r|r|}
\hline Year & \multicolumn{1}{|c|}{ India } & \multicolumn{1}{|c|}{ Nepal } & Sri Lanka & \\
\hline 1980 & 0.369 & 0.286 & 0.569 & 0.620 \\
\hline 1990 & 0.431 & 0.388 & 0.679 \\
\hline 2000 & 0.483 & 0.449 & 0.710 \\
\hline 2005 & 0.527 & 0.477 & 0.725 & \multirow{2}{*}{ HDI Values } \\
\hline 2008 & 0.554 & 0.501 & 0.738 & \\
\hline 2010 & 0.586 & 0.531 & 0.743 \\
\hline 2011 & 0.597 & 0.536 & 0.749 \\
\hline 2012 & 0.600 & 0.540 & 0.752 \\
\hline 2013 & 0.604 & 0.543 & 0.757 & \\
\hline 2014 & 0.609 & 0.548 & $\mathbf{7 5}$ & \multirow{2}{*}{ HDI Rank } \\
\hline $\mathbf{2 0 1 2}$ & $\mathbf{1 3 5}$ & $\mathbf{1 4 5}$ & $\mathbf{7 3}$ & \\
\hline $\mathbf{2 0 1 3}$ & $\mathbf{1 3 5}$ & $\mathbf{1 4 5}$ & $\mathbf{1 4 5}$ & \\
\hline $\mathbf{2 0 1 4}$ & $\mathbf{1 3 0}$ & & \\
\hline
\end{tabular}

Source: UNDP Report, $2014 \& 2015$

To glance the economic level and macroeconomic condition, Table- 3 shows the per capita income and the gross savings rate (GDS) in the three economies. Initially it comes out that Sri Lanka commands much higher per capita income (PCI as measured through PPP method) than India and Nepal. In fact, there is big gap between the PCI of Sri Lanka and India. Nepal stands at far distance as it is almost one-fifth of the Sri Lanka and less than half of the PCI of India in 2014. Nonetheless, if we look at the savings rate, the situation is different. GDS shows the capacity of an economy to generate resources domestically for investment and economic growth. This way, India seems to be on a very strong position as its savings rate is in the vicinity of 30 percent (the Economic Survey 2015-16 suggests that the GDS of India was 33 percent in 2014-15). High 
savings rate in India is being sustained for long time. Unlike India, savings rate (GDS) of Sri Lanka and Nepal has been very low. In Sri Lanka the GDS has been caged around 15 percent while the Nepalese economy is showing declining savings rate that has slipped below 10 percent. Thus, barring India, the other two economies of Sri Lanka and Nepal do not offer a clue for high macroeconomic strength. This may be derived from other macroeconomic indicators also. It is in this context that analysis of growth and structural transformation becomes important.

Table-3: Per Capita Income and Saving Rate

\begin{tabular}{|l|r|r|r|r|r|r|}
\hline \multirow{2}{*}{ Year } & \multicolumn{3}{|c|}{$\begin{array}{c}\text { GDP per capita, PPP (current } \\
\text { international \$) }\end{array}$} & \multicolumn{3}{c|}{ Gross Domestic Savings (\%) } \\
\cline { 2 - 7 } & \multicolumn{1}{|c|}{ India } & Nepal & \multicolumn{1}{|c|}{ Sri Lanka } & \multicolumn{1}{c|}{ India } & Nepal & Sri Lanka \\
\hline $\mathbf{1 9 9 0}$ & 1146.03 & 774.59 & 2377.96 & 23.5 & 6.9 & 14.3 \\
\hline $\mathbf{2 0 0 0}$ & 1998.49 & 1220.46 & 4319.07 & 23.2 & 15.2 & 17.4 \\
\hline $\mathbf{2 0 1 0}$ & 4362.85 & 1956.47 & 8173.06 & 32.1 & 11.5 & 16.8 \\
\hline $\mathbf{2 0 1 1}$ & 4685.86 & 2042.14 & 8949.31 & 31.7 & 13.9 & 15.4 \\
\hline $\mathbf{2 0 1 2}$ & 4948.33 & 2152.75 & 10159.68 & 29.9 & 10.9 & NA \\
\hline $\mathbf{2 0 1 3}$ & 5301.79 & 2247.70 & 10580.90 & 29.3 & 10.1 & NA \\
\hline $\mathbf{2 0 1 4}$ & 5700.72 & 2374.21 & 11110.19 & 29.0 & 8.9 & NA \\
\hline
\end{tabular}

Source: World Bank website

\section{The Data and Methodology}

Given the above discussion, our objective in this paper is to find out the relationship between the growth and structural transformations in the three South Asian economies of India, Nepal and Sri Lanka in the fairly long period. This would be helpful in understanding these economies in much better manner to push them forward. Although it would have been better to analyze all the eight countries of the South Asia, due to our limitations and constraints of data availability, we focus on only these three economies.

In this study we analyze growth trend in the South Asian economies of India, Sri Lanka and Nepal and also compare the structural changes in these economies with the help of Norm of Absolute Values (NAV) Index along with the growth pattern. We want to analyse the relationship between the growth rates and structural changes in the economy to understand the impact of growth rate on the structural transformation and vice versa.

Thus, in this study we consider mainly two variables which reveal the main characteristics of any developing economy - Trend Growth Rate and Structural Change Index. Trend growth rate is estimated by semi logarithmic method. The acceleration test of GDP is estimated as shown below: 
44 Agarwal \& Ritika: Growth and Structural Changes in the South Asian Economies of India, Nepal and ...

$\operatorname{Ln}(G D P)_{t}=a+b t+c t^{2}$

Where $t$ is time, taking values 1 for the first year of each sub period. Slope $b$ is interpreted as average annual trend growth and $c$ is interpreted as shift parameter which is defined as rate of acceleration or deceleration in the average growth as the case may be depending upon its sign.

Since the data available is not fully comparable in terms of series, length and pattern in these three economies, we have made efforts to get them broadly comparable. Still, we acknowledge it a major limitation for comparable analysis.

Our analysis separately covers the five sub periods for India as 1950-51 to 1964-65; 1965-66 to 1978-79; $1980-81$ to $1990-91$; $1991-92$ to 2003-04; and 2004-05 to 2012-13. For Sri Lanka and Nepal it is divided into four and three sub periods respectively. For Sri Lanka it is as 1970-81; $1982-95$; 1996-2001; and 2002-2013. For Nepal it is as $1984-85$ to $1988-89$; $1989-90$ to $2004-$ 05; and 2005-06 to 2014-15. These sub periods are chosen on the basis of growth performance of the respective economies. Gross Domestic Product (GDP) data and calculated data for given economies are collected from different sources like Statistical Year book 2014 of India, Economic Survey 2014 of Nepal and Annual Report 2014, Central Bank of Sri Lanka. Data is also taken from the World Bank publications, etc.

We also use the structural change index as a variable. It is well known that structural changes occur in both demand and supply sides of the economy. A structural change in demand side occurs on account of a change in quantity and composition of the good or output in the process of the economic growth. On the supply side, learning and technological change can lead to productivity improvement. In order to estimate the structural change process, we need an index to quantify its magnitude. In this study we use the same index 'Norm of Absolute Value' (NAV) as in Cortuk and Singh (2015). This index is used to measure average structural change, without discussing the productivity changes. The index is estimated as shown below:

$$
N A V=0.5 \sum_{i=1}^{n} \mid x_{i t}-x \text { is } \mid
$$

For computation of this index, first, the differences of the sector share $\mathrm{x}_{\mathrm{i}}$ between two points of time, $s$ and $t$, are calculated. Then the absolute amounts of these differences are summed up and divided by two (since each change is counted twice). The result is a range of NAV from 0 to 1 . Thus, that the interpretation of NAV index is quite simple. This indicates that the structural change is exactly equal to the share of movement of sectors as a percentage of the whole economy. If structure remains unchanged, index is equal to zero. If change in all sectors is at its highest, it means the whole economy undergoes a total change; the index is equal to unity. For this study estimation is done for different sub-sectors' share of GDP data of the three countries, viz, India, Sri Lanka, and Nepal. We report the mean for NAV index for each country's different sub-sectors of the GDP, estimated for the different sub-periods. We somewhat modify the analysis from 
Kortuk and Singh (2015) to improve the analysis and inferences. This would be discussed while going through the process of analysis later in the paper.

\section{Economic Growth Accelaration in Three Countries}

\subsection{Growth and Acceleration in the Indian Economy}

Indian economy is the largest economy in the South Asia with a total population of over 1.21 billion in 2011. Its population size is much larger than the total population of the other SAARC member countries taken together. Indian economy is now poised to be the fastest growing economy around the world after taking over the growth rate of the Chinese economy. We may now analyze the growth pattern of the Indian economy. For the Indian economy it would be befitting to suggest that India is a fast upcoming economy at the global level. The Economic Survey 2015-16 of India puts it candidly that "The global economy, in particular, the global growth powerhouse, China - is rebalancing, leading to an increasing role for India. After the onset of the multiple crises in different parts of the world, India's continuation has become much more vulnerable to the global economy" (Vol. II, p. 3). It further notes down that the India's share in the world GDP has increased from an average of 4.8 percent during 2001-07 to 6.1 percent during 2008-13 and further to an average of 7.0 percent during 2014 to 2015 in current PPP terms (IMF), India's resilience and current levels of reasonably strong growth should, thus, be appreciated in the light of its increasing contribution to global growth (ibid., p.3).

However, we may look at the growth pattern of the Indian economy over a period of time. Besides, we shall be also making acceleration test to gauge the nature of the growth. This could be for the national income (GDP) and sub-sectors. We have estimated semi-logarithmic growth also known as the trend growth rate. We have also undertaken the acceleration test as illustrated earlier also known as quadratic estimation. We find from Table-4 that Indian economy has been making an impressive growth performance. The growth behavior of the Indian economy has been estimated for the five sub-periods: $1950-51$ to $1964-65$; $1965-66$ to $1980-81 ; 1981-82$ to $1990-91$; 1991 92 to 2003-04; and 2004-05 to 2012-13. Indian economy has been consistently making upward movement during these sub-periods. As a result, the growth rate in the Indian economy almost doubled during the latest sub-period of 2004-05 to 2012-13 from what could be realized during the initial two sub-periods when it was capped at 4 percent a year. During the decade of the 1980 s the growth rate picked up to almost 5 percent a year to increase further to above 5 percent a year during the initial decade of the economic reforms in India (1991-92 to 2003-04). What has been more obvious is that the growth pattern has been continuously moving upward from one sub-period to the next sub-period. Still, the acceleration test has been estimated in negative for two sub-periods of 1965-66 to 1980-81 and the latest sub-period of 2004-05 to 2012-13. Therefore, although the Indian economy has been making consistent efforts to improve its growth performance during the successive periods, it requires greater efforts to accelerate the economic growth during the successive periods. 
Agarwal \& Ritika: Growth and Structural Changes in the South Asian Economies of India, Nepal and ...

Table-4: Trend Growth Rate and Acceleration Test of GDP in India

\begin{tabular}{|c|c|c|c|c|c|c|c|c|c|c|}
\hline \multicolumn{11}{|c|}{ INDIA } \\
\hline \multirow{2}{*}{ Sectors } & \multicolumn{2}{|c|}{$\begin{array}{l}1950-51 \text { to } \\
1964-65\end{array}$} & \multicolumn{2}{|c|}{$\begin{array}{l}1965-66 \text { to } \\
1980-81\end{array}$} & \multicolumn{2}{|c|}{$\begin{array}{l}1981-82 \text { to } \\
1990-91\end{array}$} & \multicolumn{2}{|c|}{$\begin{array}{l}1991-92 \text { to } \\
2003-04\end{array}$} & \multicolumn{2}{|c|}{$\begin{array}{c}2004-05 \text { to } \\
2012-13\end{array}$} \\
\hline & $\begin{array}{r}\text { Accl. } \\
\text { Test }\end{array}$ & TGR & $\begin{array}{l}\text { Accl. } \\
\text { Test }\end{array}$ & TGR & $\begin{array}{l}\text { Accl. } \\
\text { Test }\end{array}$ & TGR & $\begin{array}{l}\text { Accl. } \\
\text { Test }\end{array}$ & TGR & $\begin{array}{r}\text { Accl. } \\
\text { Test }\end{array}$ & TGR \\
\hline $\begin{array}{l}\text { agriculture, incl. } \\
\text { livestock }\end{array}$ & $\mathrm{N}$ & 2.65 & $\mathrm{~N}$ & 3.43 & $\mathrm{~N}$ & 3.09 & $\mathrm{~N}$ & 2.35 & $\mathrm{~N}$ & 3.55 \\
\hline forestry \& logging & A & 1.09 & $\mathrm{D}$ & 1.00 & A & -0.04 & A & 1.56 & $\mathrm{~N}$ & 2.28 \\
\hline Fishing & $\mathrm{N}$ & 4.61 & $\mathrm{D}$ & 3.92 & $\mathrm{~N}$ & 5.69 & $\mathrm{D}$ & 3.49 & $\mathrm{~N}$ & 3.87 \\
\hline mining \& quarrying & A & 5.39 & A & 3.45 & $\mathrm{~A}$ & 7.15 & $\mathrm{~N}$ & 3.44 & $\mathrm{~N}$ & 1.54 \\
\hline Manufacturing & A & 6.30 & $\mathrm{~N}$ & 4.49 & A & 5.19 & $\mathrm{~N}$ & 4.91 & $\mathrm{~N}$ & 7.69 \\
\hline $\begin{array}{l}\text { electricity, gas \& water } \\
\text { supply }\end{array}$ & A & 7.25 & $\mathrm{~N}$ & 12.30 & A & 7.14 & $\mathrm{D}$ & 1.98 & $\mathrm{D}$ & 4.57 \\
\hline Construction & A & 6.67 & $\mathrm{~N}$ & 2.63 & $\mathrm{~A}$ & 4.48 & A & 5.77 & $\mathrm{~N}$ & 7.36 \\
\hline $\begin{array}{l}\text { trade, hotels \& } \\
\text { restaurants }\end{array}$ & A & 5.68 & $\mathrm{~A}$ & 4.51 & A & 5.85 & A & 8.33 & $\mathrm{D}$ & 7.80 \\
\hline $\begin{array}{l}\text { transport, storage \& } \\
\text { communication }\end{array}$ & A & 6.81 & $\mathrm{~N}$ & 7.39 & A & 5.61 & A & 7.44 & $\mathrm{~N}$ & 11.91 \\
\hline banking \& insurance & A & 7.34 & A & 7.60 & A & 11.05 & $\mathrm{~N}$ & 8.97 & A & 14.78 \\
\hline $\begin{array}{l}\text { real estate, ownership of } \\
\text { dwellings }\end{array}$ & $\mathrm{D}$ & 8.93 & $\mathrm{D}$ & 5.10 & A & 8.11 & A & 5.87 & A & 8.87 \\
\hline $\begin{array}{l}\text { public Administration \& } \\
\text { defence }\end{array}$ & A & 5.91 & $\mathrm{~N}$ & 6.47 & A & 6.81 & $\mathrm{~N}$ & 5.69 & $\mathrm{~N}$ & 8.69 \\
\hline other services & A & 3.14 & $\mathrm{~N}$ & 3.08 & A & 5.38 & A & 6.79 & A & 6.16 \\
\hline GDP & A & 3.98 & $\mathrm{~N}$ & 4.00 & A & 4.99 & A & 5.35 & $\mathrm{~N}$ & 7.84 \\
\hline
\end{tabular}

Source: Estimated from the data in Statistical Year Book of India 2014

Note: A: Acceleration, D: Deceleration, N: No sign of acceleration

Sectoral growth behavior of the Indian economy brings out many more vital clues about the nature of this rapidly emerging economy that still has huge untapped growth potentialities. Table-5, in this regard, provides a meaningful insight into the growth at the disaggregated levels for the same 
sub-periods. If the economy is split into three sectors (primary, secondary and tertiary sectors) it is found that the primary sector's growth rate has been generally low and it has been around 3 percent or lower. There is generally no evident trend of improvement during different subperiods. Moreover, the primary sector has always behaved with sluggishness as it could not clear the acceleration test in any of the sub-periods. This is despite the fact that in India, a large section, rather majority, of the population still depends upon the agriculture or the primary sector. The agricultural sector has also been getting modernized in several ways.

Disaggregated analysis provides a picture different from the growth experiences of the aggregated GDP. The secondary sector, that also includes the important manufacturing sector, has been performing inconsistently unlike the GDP growth trend. The growth trend of the secondary sector has been varying in terms of the quantum showing instable growth in the secondary sector as it went down from 6.40 percent a year during 1950-65 to 4.22 percent a year in the succeeding period of 1965-79 to rise again marginally to 5.12 percent during 1980-91 and to trim again to 4.96 percent during 1991-2004 and ultimately rising to 7.49 percent in the latest sub-period. In terms of the acceleration test, it is found that only during the two sub-periods, it tested positive while during the two sub-periods acceleration could not be tested significantly while during the latest period, the secondary sector has been suffering from deceleration despite surge in growth rate.

The other non-farm sector is the services sector that has become the predominant one now in the Indian economy. It contributes more than 53 percent to the GDP. It has contributed somewhat more than one-quarter during the first sub-period. Thus, there has been major structural change in the Indian economy. Growth pattern of this sector has been more consistent and relatively robust. The annual growth rate of the services sector was 5.57 percent during the initial sub-period of 1950-65. It moderated to 5.07 percent in the subsequent sub-period (1965-79). Thereafter, there has been improved growth performance of the services sector. It has reached near the double digit (9.46 percent a year) during the latest sub-period (2004-13). Despite maintaining higher growth, this sector has also not been able to show accelerated growth during the latest sub-period and also during the sub-period of 1965-79. Otherwise, there has been acceleration in growth. Comparison with the primary and secondary sectors shows that the services sector has been more consistent and showing better overall growth performance besides acceleration in its growth on more occasions. This is growing debate now that the services sector has been the engine of economic growth in the Indian economy. We may provide some view from the different issues of Economic Survey. Economic Survey 2013-14 acknowledges the robust growth of the services sector in the Indian economy (2014; p.7). Even the Economic Survey 2015-16 acknowledges the robust growth of the services sector despite some moderation in the recent period (2016; p.7). 
Agarwal \& Ritika: Growth and Structural Changes in the South Asian Economies of India, Nepal and ...

Table-5: Sectoral Share, Trend Growth Rate and Acceleration Test in India

\begin{tabular}{|c|c|c|c|}
\hline Sectors $\rightarrow$ & \multirow{2}{*}{ Primary Sector } & \multirow{2}{*}{ Secondary Sector } & \multirow{2}{*}{ Tertiary Sector } \\
\hline Parameters $\downarrow$ & & & \\
\hline \multicolumn{4}{|c|}{$1950-51$ to $1964-65$} \\
\hline Share $(\%)$ & 51.55 & 22.05 & 26.40 \\
\hline Trend Growth Rate (\%) & 2.45 & 6.40 & 5.57 \\
\hline Acceleration Test & $\mathrm{N}$ & $\mathrm{A}$ & A \\
\hline \multicolumn{4}{|c|}{$1965-66$ to $1978-79$} \\
\hline Share $(\%)$ & 40.82 & 27.57 & 31.60 \\
\hline Trend Growth Rate (\%) & 2.93 & 4.22 & 5.07 \\
\hline Acceleration Test & $\mathrm{N}$ & $\mathrm{N}$ & $\mathrm{N}$ \\
\hline \multicolumn{4}{|c|}{$1980-81$ to $1990-91$} \\
\hline Share $(\%)$ & 33.69 & 28.74 & 37.56 \\
\hline Trend Growth Rate (\%) & 3.07 & 5.12 & 6.64 \\
\hline Acceleration Test & $\mathrm{N}$ & A & A \\
\hline \multicolumn{4}{|c|}{ 1991-92 to 2003-04 } \\
\hline Share $(\%)$ & 26.41 & 28.41 & 45.18 \\
\hline Trend Growth Rate (\%) & 2.42 & 4.96 & 7.28 \\
\hline Acceleration Test & $\mathrm{N}$ & $\mathrm{N}$ & $\mathrm{A}$ \\
\hline \multicolumn{4}{|c|}{ 2004-05 to 2012-13 } \\
\hline Share $(\%)$ & 17.18 & 29.74 & 53.08 \\
\hline Trend Growth Rate (\%) & 3.22 & 7.49 & 9.46 \\
\hline Acceleration Test & $\mathrm{N}$ & $\mathrm{D}$ & $\mathrm{N}$ \\
\hline
\end{tabular}

Source: Estimated from the data in Statistical Year Book 2014

Note: $A$ : Acceleration, $D$ : Deceleration, $N$ : No sign of acceleration

\subsection{Growth and Acceleration in the Sri Lankan Economy}

Sri Lanka is an important economy in South Asia and it is also considered to be an upcoming economy. In this Island economy, economic reforms were initiated first among other South Asian members in the 1970s. We can analyze the growth trend in this country after doing so for the Indian economy. However, the overall period and sub-periods of the country would be differing due to economic situations and their data series and also their availability. Despite this, the analysis and inferences would not be impacted in any significant manner. There are four subperiods for which the analysis is undertaken for Sri Lanka: 1970-1981; 1982-1995; 1996-2001; and 2002-2013. Overall period of analysis in Sri Lanka has been smaller than in India and this is due to lack of availability of the data series on comparable basis. 
Growth rate of the Sri Lankan economy remained capped around 4 percent a year for fairly long period. Tables $6 \& 7$ suggest that growth rates during the first three sub-periods remained around 4.25 percent a year and this cannot be considered a high growth rate considering Sri Lanka being a developing economy. The acceleration test shows that it was positive for the initial two sub-periods of 1970-1981 and 1982-1995 while the economic growth lacked the acceleration during 1996-2001. The growth rate became more forceful in the latest period of 2002-13 when for the first time Sri Lankan GDP growth rate dismantled the growth cap of around 4 percent. Now it becomes 6.46 percent a year and a big jump over the preceding growth realizations. Several factors are considered to be contributing for this growth momentum like the end of the war within the nation and other economic factors. Moreover, there has been acceleration in the growth realization during this period and this is shared by many sub-sectors as may be seen from Table-8. Thus, the Sri Lankan economy has now come out from the caged economic growth rate of around 4 percent. It is making efforts to grow at faster rate and trying to reach the growth trend being sustained by the Indian economy at high level. This augurs well for the regional growth in the SAARC region.

Table-6: Trend Growth Rate and Acceleration Test of GDP in Sri Lanka

\begin{tabular}{|l|c|c|c|c|}
\hline \multirow{2}{*}{ Sectors } & \multicolumn{2}{|c|}{ 1970-1981 } & \multicolumn{2}{c|}{ 1982-1995 } \\
\cline { 2 - 5 } & $\begin{array}{c}\text { Acceleration } \\
\text { Test }\end{array}$ & $\begin{array}{c}\text { TGR } \\
\text { (percent) }\end{array}$ & $\begin{array}{c}\text { Acceleration } \\
\text { Test }\end{array}$ & $\begin{array}{c}\text { TGR } \\
\text { (percent) }\end{array}$ \\
\hline $\begin{array}{l}\text { Agriculture, Foresting \& } \\
\text { Fishing }\end{array}$ & $\mathrm{A}$ & 3.04 & $\mathrm{~N}$ & 1.98 \\
\hline Mining \& Quarring & $\mathrm{N}$ & 21.70 & $\mathrm{~N}$ & 4.70 \\
\hline Manufacturing & $\mathrm{A}$ & 2.13 & $\mathrm{~A}$ & 7.35 \\
\hline Construction & $\mathrm{A}$ & 3.76 & $\mathrm{~A}$ & 2.82 \\
\hline $\begin{array}{l}\text { Electricity, Gas \& Water } \\
\text { Supply }\end{array}$ & $\mathrm{A}$ & 8.68 & $\mathrm{~A}$ & 6.35 \\
\hline $\begin{array}{l}\text { Transport, Storage \& } \\
\text { Communication }\end{array}$ & $\mathrm{A}$ & 3.99 & $\mathrm{~A}$ & 4.05 \\
\hline Trade & $\mathrm{A}$ & 4.60 & $\mathrm{~A}$ & 4.50 \\
\hline $\begin{array}{l}\text { Banking, Insurance \& Real } \\
\text { Estate }\end{array}$ & $\mathrm{A}$ & 10.55 & $\mathrm{~A}$ & 6.94 \\
\hline Ownership of Dwelling & $\mathrm{A}$ & 3.32 & $\mathrm{D}$ & 1.46 \\
\hline $\begin{array}{l}\text { Public Administration \& } \\
\text { Defence }\end{array}$ & $\mathrm{N}$ & 6.21 & $\mathrm{D}$ & 6.04 \\
\hline Other Services & $\mathrm{A}$ & 5.69 & $\mathrm{~A}$ & 2.74 \\
\hline GDP & $\mathrm{A}$ & 4.29 & $\mathrm{~A}$ & 4.24 \\
\hline
\end{tabular}


Table-7: Trend Growth Rate and Acceleration Test of GDP in Sri Lanka during 1996 - 2001

\begin{tabular}{|l|c|c|}
\hline \multicolumn{1}{|c|}{ Sectors } & $\begin{array}{c}\text { Acceleration } \\
\text { Test }\end{array}$ & $\begin{array}{c}\text { TGR } \\
\text { (percent) }\end{array}$ \\
\hline Agriculture, Foresting \& Fishing & $\mathrm{D}$ & 2.06 \\
\hline Mining \& Quarrying & $\mathrm{N}$ & 1.47 \\
\hline Manufacturing & $\mathrm{N}$ & 5.30 \\
\hline Construction & $\mathrm{D}$ & 5.07 \\
\hline Electricity, Gas \& Water Supply & $\mathrm{D}$ & 6.43 \\
\hline Transport, Storage \& Communication & $\mathrm{N}$ & 7.39 \\
\hline Wholesale and Retail Trade, Hotel and Restaurants & $\mathrm{N}$ & 3.10 \\
\hline Financial Services, Real Estate and Business Services & $\mathrm{N}$ & 5.71 \\
\hline Public Administration, Other Govt. Services and Defence & $\mathrm{N}$ & 3.98 \\
\hline GDP & $\mathrm{N}$ & 4.22 \\
\hline
\end{tabular}

Table-8: Trend Growth Rate and Acceleration Test of GDP in Sri Lanka during 2002 - 2013

\begin{tabular}{|l|c|c|}
\hline Sectors & Acceleration Test & TGR (percent) \\
\hline Agriculture, Foresting & $\mathrm{N}$ & 3.85 \\
\hline Fishing & $\mathrm{A}$ & 6.80 \\
\hline Mining \& Quarring & $\mathrm{A}$ & 15.50 \\
\hline Manufacturing & $\mathrm{A}$ & 5.74 \\
\hline Construction & $\mathrm{A}$ & 9.57 \\
\hline Electricity, Gas \& Water Supply & $\mathrm{N}$ & 7.40 \\
\hline Transport, Storage \& Communication & $\mathrm{A}$ & 9.63 \\
\hline Wholesale and Retail Trade & $\mathrm{N}$ & 5.78 \\
\hline Hotel and Restuants & $\mathrm{A}$ & 13.22 \\
\hline Banking, Insurance \& Real Estate & $\mathrm{A}$ & 7.31 \\
\hline Ownership of Dwelling & $\mathrm{A}$ & 1.23 \\
\hline Government Services & $\mathrm{N}$ & 4.48 \\
\hline Private Services & $\mathrm{A}$ & 6.36 \\
\hline GDP & $\mathrm{A}$ & 6.46 \\
\hline
\end{tabular}

Source: Estimated from the data in Economic and Social Statistics 2014, Central Bank of Sri Lanka

Note: A: Acceleration,D: Deceleration, N: No sign of acceleration

Sectoral growth behavior in Sri Lanka suggests that it has been faster than in India for the primary sector although the growth rates have been faster in the latter. Table- 9 suggests that the primary sector contributed somewhat more than one-quarter of the total GDP (26.20 percent) during 1970-81. Now it has been reduced to less than half (12.33 percent) during 2002-13. Its growth rate has also been varying widely. It was around 3 percent during the 1970s that declined to around 2 percent during the two succeeding decades. During 2002-13, the growth rate of 
the primary sector has become high (4.13 percent). This is very high if we consider historical growth record of Sri Lanka. However, the secondary sector seems not to be the beneficiary of the trimming of the primary sector as its contribution to the Sri Lankan GDP increased marginally from around 24 percent to around 29 percent during the study period whereas the growth rate improved considerably during the latest sub-period. It is ironical for the Island economy that whereas the tertiary sector is gaining profusely in terms of its share in the country's GDP, its growth performance has not been better than the secondary sector.

Growth rate of the tertiary sector was almost 5 percent during the 1970s. It declined to below 5 percent in the two subsequent sub-periods. It rose to almost 6.5 percent during the latest subperiod of 2002-13. This is lower than the secondary sector's growth rate (7.41 percent). On the other hand, share of the tertiary or the services sector was around 50 percent during the $1970 \mathrm{~s}$. This has gone up to 59 percent during 2002-13. This trend is somewhat dissimilar to the Indian economy where the tertiary sector has been the fastest growing sector and has the largest share in the GDP of the Indian economy. Still, share of the tertiary sector in the Indian economy is slightly lower than what it has been in the Island economy. Besides, only the tertiary sector suffered from deceleration during 1982-95. The other two sectors did not suffer from deceleration during any of the sub-periods. Thus, the Sri Lankan economy seems to improve its growth rate sufficiently. The sectoral behavior remains to be understood carefully just as in the case of the Indian economy.

Table-9: Sectoral Share, Trend Growth Rate and Acceleration Test in Sri Lanka

\begin{tabular}{|c|c|c|c|}
\hline Sectors $\rightarrow$ & \multirow{2}{*}{ Primary Sector } & \multirow{2}{*}{ Secondary Sector } & \multirow{2}{*}{ Tertiary Sector } \\
\hline Parameters $\downarrow$ & & & \\
\hline \multicolumn{4}{|c|}{ 1970- 81} \\
\hline Share $(\%)$ & 26.20 & 23.56 & 50.24 \\
\hline Trend Growth Rate (\%) & 3.04 & 4.16 & 5.01 \\
\hline Acceleration Test & $\mathrm{A}$ & $\mathrm{A}$ & $\mathrm{A}$ \\
\hline \multicolumn{4}{|c|}{ 1982-95 } \\
\hline Share (\%) & 23.40 & 27.85 & 48.75 \\
\hline Trend Growth Rate (\%) & 1.98 & 5.85 & 4.42 \\
\hline Acceleration Test & $\mathrm{N}$ & $\mathrm{A}$ & $\mathrm{D}$ \\
\hline \multicolumn{4}{|c|}{ 1996-2001 } \\
\hline Share (\%) & 21.21 & 27.08 & 51.71 \\
\hline Trend Growth Rate (\%) & 2.06 & 5.03 & 4.70 \\
\hline Acceleration Test & $\mathrm{A}$ & $\mathrm{N}$ & $\mathrm{N}$ \\
\hline \multicolumn{4}{|c|}{$2002-2013$} \\
\hline Share (\%) & 12.23 & 28.73 & 59.04 \\
\hline Trend Growth Rate (\%) & 4.13 & 7.41 & 6.48 \\
\hline Acceleration Test & $\mathrm{A}$ & $\mathrm{A}$ & $\mathrm{A}$ \\
\hline
\end{tabular}

Source: Estimated from data given in Economic and Social Statistics of Sri Lanka 2014, Central Bank of Sri Lanka

Note: $A$ : Acceleration, $D$ : Deceleration, $N$ : No sign of acceleration 


\subsection{Growth and Acceleration in the Nepalese Economy}

Nepal is a prominent nation in South Asia. it is also described as the Himalayan Kingdom. This South Asian economy is land-locked and hence has its own challenges. This Himalayan economy has not been known for major economic initiatives but is well known for tourism attractions. Nonetheless it has been showing signs of betterment at times and then getting marred by the political quagmire (Agarwal and Upadhyay, 2006). Unlike the Sri Lanka, located south of India, the Nepal, located north of India does not imbibe much sense of confidence in terms of improvements in the growth rates. We have analyzed the Nepalese economy for relatively shorter period of 1984-85 to 2014-15. This overall period has been divided into three sub-periods: 198489; 1989-2005; and 2005-14. Ironically again, the Nepalese economy tends to reveal lower and lower growth rates over the successive sub-periods from 4.53 percent in the initial sub-period to 4.27 percent during the next sub-period and finally 4.22 percent a year during the last sub-period of 2005-14 (Tables $10 \& 11$ ). It is also to be noted that the acceleration test for the economic growth in Nepal has been positive only during the latest sub-period of 2005-14. This brings out that the Nepalese economy is trapped into low growth levels unlike the Indian and the Sri Lankan economies.

Table-10: Trend Growth Rate and Acceleration Test of GDP in Nepal during 1984 - 2005

\begin{tabular}{|l|c|c|c|c|}
\hline Sectors & $\begin{array}{c}\text { Acceleration } \\
\text { Test }\end{array}$ & TGR (percent) & Accel.Test & $\begin{array}{c}\text { TGR } \\
\text { (percent) }\end{array}$ \\
\hline $\begin{array}{l}\text { Agriculture, Fisheries and } \\
\text { Forestry }\end{array}$ & A & 3.48 & A & 2.92 \\
\hline Mining and Quarring & A & 7.56 & D & 4.57 \\
\hline Manufacturing & D & 3.78 & D & 5.58 \\
\hline Electricity, Gas and Water & D & 10.15 & A & 8.51 \\
\hline Construction & A & 8.15 & D & 4.74 \\
\hline $\begin{array}{l}\text { Trade, Restaurants \& } \\
\text { Hotels }\end{array}$ & D & 5.07 & D & 3.92 \\
\hline $\begin{array}{l}\text { Transport, Communications } \\
\text { \& Storage }\end{array}$ & D & 4.09 & N & 6.97 \\
\hline Financial \& Real Estate & A & 4.83 & D & 4.82 \\
\hline $\begin{array}{l}\text { Community \& Social } \\
\text { Services }\end{array}$ & A & 8.09 & N & 5.92 \\
\hline GDP & N & 4.53 & N & 4.27 \\
\hline
\end{tabular}


Table-11: Trend Growth Rate and Acceleration Test of GDP in Nepal during 2005 - 2014

\begin{tabular}{|l|c|c|}
\hline Sectors & Accel.Test & TGR (percent) \\
\hline Agriculture and forestry & $\mathrm{N}$ & 3.13 \\
\hline Fishing & $\mathrm{A}$ & 5.20 \\
\hline Mining and Quarrying & $\mathrm{N}$ & 2.85 \\
\hline Manufacturing & $\mathrm{A}$ & 2.68 \\
\hline Electricity gas and water & $\mathrm{N}$ & 2.88 \\
\hline Construction & $\mathrm{N}$ & 3.58 \\
\hline Wholesale and retail trade & $\mathrm{A}$ & 4.40 \\
\hline Hotels and restaurants & $\mathrm{A}$ & 5.68 \\
\hline Transport, storage and communications & $\mathrm{A}$ & 6.95 \\
\hline Financial intermediation & $\mathrm{D}$ & 3.46 \\
\hline Real estate, renting and business activities & $\mathrm{D}$ & 4.12 \\
\hline Public Administration and defence & $\mathrm{A}$ & 4.26 \\
\hline Education & $\mathrm{N}$ & 6.09 \\
\hline Health and social work & $\mathrm{N}$ & 6.32 \\
\hline Other community, social and personal service activities & $\mathrm{D}$ & 8.62 \\
\hline GDP & $\mathrm{A}$ & 4.22 \\
\hline
\end{tabular}

Source: Estimated from data given in Economic Survey of Nepal 2005, 2014

Note: A: Acceleration, D: Deceleration, $N$ : No sign of acceleration

Table-12 suggests that the pace of structural transformation has been quite slow when compared with the neighbouring economy of India or even the Sri Lankan economy. Share of the primary sector in the Nepalese GDP was almost 50 percent during the 1980s and it has come down to almost 35 percent in the latest sub-period of 2005-14. This is almost the double of the other two economies being studied here. The secondary sector gives a very different impression as its share first increased from around 16 percent during the 1980 s to 22.18 percent during 1989-90 to 2004-05 and later got reversed to again below 16 percent level. This indicates poor state of industrialization in the Nepalese economy, on the one hand, and on the other hand, it suggests that industrialization is not a strong feature of the Nepalese economy that may be sustained during the adverse economic scenario. Agarwal and Upadhyay (2006; p.58) have estimated that growth rate of the economy was very low at 2.14 percent during 1964-75. This doubled to 4.23 percent during 1975-91. They show that sectoral growth rates also improved wherein industry and services sector grew faster. They estimate that the agriculture grew 2.44 percent during 1964-65 to 2001-02 when the GDP grew by 4.25 percent. During this period industrial sector grew by 6.43 percent while the services sector grew by 6.41 percent. Like the other two economies of the South Asia, the Himalayan economy is also making consistent improvement in the share of the services sector as its share has gone up from the 34.52 percent during the 1980 s to almost half of the GDP in the 
latest sub-period. Sectoral growth behavior shows that the farm sector or the primary sector is maintaining a growth rate of around 3 percent although there has been small moderation. The poor situation is reflected for the secondary sector where there has been a sharp decline in growth rates from 6.60 percent during 1984-89 to 5.34 percent during 1989-2005. Now it has come down to the lowest of 3.05 percent per annum during 2005-15. In fact, during the latest sub-period, growth rate of the secondary sector has been lower than the growth rate of the primary sector. Hence, it appears that there is some deep rooted economic problem particularly with regard to growth and structural transformation. Even the tertiary sector seems to record lower growth rate than what it recorded during the initial sub-period. On the whole, its growth rate remains caged below 6 percent. Besides, all the three sectors in all the sub-periods have not shown accelerated growth performance barring the primary sector in the initial sub-period. Thus, the Nepalese economy seems to be trapped in a situation of low growth and poor structural transformations.

Table-12: Sectoral Share, Trend Growth Rate and Acceleration Test in Nepal

\begin{tabular}{|l|c|c|c|}
\hline \multirow{2}{*}{ Sectors $\rightarrow$} & \multirow{2}{*}{ Primary Sector } & \multirow{2}{*}{ Secondary Sector } & \multirow{2}{*}{ Tertiary Sector } \\
\cline { 1 - 3 } Parameters $\downarrow$ & $\mathbf{1 9 8 4 - 8 5}$ to 1988-89 \\
\cline { 1 - 3 } Share (\%) & 49.64 & 15.83 & 34.52 \\
\hline Trend Growth Rate (\%) & 3.48 & 6.60 & 5.62 \\
\hline Acceleration Test & $\mathrm{A}$ & $\mathrm{N}$ & $\mathrm{N}$ \\
\hline \multicolumn{5}{|c|}{$\mathbf{1 9 8 9 - 9 0}$ to 2004-05 } \\
\hline Share (\%) & 40.78 & 22.18 & 37.04 \\
\hline Trend Growth Rate (\%) & 2.92 & 5.34 & 5.23 \\
\hline Acceleration Test & $\mathbf{2 0 0 5 - 0 6}$ to 2014-15 & $\mathrm{N}$ \\
\hline \multicolumn{5}{|c|}{34.95} & 15.73 & 49.32 \\
\hline Share (\%) & 3.16 & 3.05 & 5.37 \\
\hline Trend Growth Rate (\%) & $\mathrm{N}$ & $\mathrm{N}$ & $\mathrm{N}$ \\
\hline Acceleration Test &
\end{tabular}

Source: Estimated from data given in Economic Survey 2014 of Nepal

Note: $A$ : Acceleration, $D$ : Deceleration, $N$ : No sign of acceleration

\section{Structural change and Economic Growth}

Structural change is very important for any developing economy to move forward or the growth must lead to structural transformations in the economy. This is required so as to shift the sources of economic growth in the economy as it moves forward. For example, as the economy grows from very low level, people may prefer to consume more of the non-agricultural items and this would require more prominence to the non-agricultural activities. Thus, structural transformation is an essential ingredient of any developing economy to realize more and more growth and meet the consumer demands on the economy. 
In the various tables (13 to18), we have measured the structural changes for the three economies. These structural changes are estimated for different sub-periods for an economy as defined earlier. In fact the structural change measured through the NAV shows the average change in the share of the sub-sector in the overall GDP. This suggests that there has been varying degrees of change among the different sub-sectors in a given sub-period. We find that the degree of change among the sub-sectors has not been the same just as we have seen that the growth rates have been varying across the sub-sectors in a sub-period. This holds true for all the three countries. However, it may be found that the coefficient of variation has been very high generally in all the sub-periods of the three countries. This clearly brings out that there has been changing degrees of variations and there have been wide gaps in structural transformations. Hence, it would be prudent to test this structural transformation with the growth rates to understand the pattern of interdependence between the structural changes and growth rates.

Table 13: Estimation of the NAV for India

\begin{tabular}{|c|c|c|c|c|c|}
\hline Sectors & $\begin{array}{c}1950-51 \\
\text { to } \\
1964-65\end{array}$ & $\begin{array}{c}1965-66 \\
\text { to } \\
1979-80\end{array}$ & $\begin{array}{c}1980-84 \\
\text { to } \\
1990-91\end{array}$ & $\begin{array}{c}1991-92 \\
\text { to } \\
2003-04\end{array}$ & $\begin{array}{c}2004-05 \\
\text { to } \\
2012-13\end{array}$ \\
\hline Agriculture, incl. livestock & .0283 & .0229 & .0221 & .0321 & .0221 \\
\hline Forestry \& logging & .0270 & .0208 & .0118 & .0078 & .0039 \\
\hline Fishing & .0006 & .0001 & .0002 & .0008 & .0010 \\
\hline Mining \& quarrying & .0017 & .0006 & .0039 & .0035 & .0054 \\
\hline Manufacturing & .0247 & .0106 & .0029 & .0033 & .0017 \\
\hline $\begin{array}{l}\text { Electricity, gas \& water } \\
\text { supply }\end{array}$ & .0007 & .0046 & .0013 & .0024 & .0014 \\
\hline Construction & .0097 & .0043 & .0013 & .0016 & .0008 \\
\hline Trade, hotels \& restaurants & .0097 & .0048 & .0045 & .0240 & .0003 \\
\hline $\begin{array}{l}\text { Transport, storage \& } \\
\text { communication }\end{array}$ & .0039 & .0105 & .0011 & .0090 & .0129 \\
\hline Banking \& insurance & .0024 & .0047 & .0080 & .0085 & .0213 \\
\hline $\begin{array}{l}\text { Real estate, ownership of } \\
\text { dwellings }\end{array}$ & .0126 & .0055 & .0096 & .0025 & .0050 \\
\hline $\begin{array}{l}\text { Public Administration \& } \\
\text { defence }\end{array}$ & .0042 & .0094 & .0027 & .0019 & .0009 \\
\hline Other services & .0044 & .0012 & .0010 & .0054 & .0045 \\
\hline CV $(\%)$ & 102.17 & 93.11 & 114.25 & 119.90 & 122.13 \\
\hline
\end{tabular}

Source: Estimated from data given in Statistical Year Book 2014 of India 
56 Agarwal \& Ritika: Growth and Structural Changes in the South Asian Economies of India, Nepal and ...

Table 14: Estimation of the NAV for Sri Lanka

\begin{tabular}{|l|c|c|}
\hline Sectors & $\mathbf{1 9 7 0 - 1 9 8 1}$ & $\mathbf{1 9 8 2 - 1 9 9 5}$ \\
\hline Agriculture, Foresting \& Fishing & .0184 & .0316 \\
\hline Mining \& Quarrying & .0136 & .0002 \\
\hline Manufacturing & .0152 & .0076 \\
\hline Construction & .0032 & .0019 \\
\hline Electricity, Gas \& Water Supply & .0018 & .0004 \\
\hline Transport, Storage \& Communication & .0004 & .0029 \\
\hline Trade & .0014 & .0093 \\
\hline Banking, Insurance \& Real Estate & .0054 & .0084 \\
\hline Ownership of Dwelling & .0011 & .0062 \\
\hline Public Administration \& Defence & .0045 & .0057 \\
\hline Other Services & .0118 & .0057 \\
\hline CV (\%) & $\mathbf{9 3 . 2 4}$ & $\mathbf{1 1 9 . 1 2}$ \\
\hline
\end{tabular}

Table 15: Estimation of the NAV for Sri Lanka

\begin{tabular}{|l|c|}
\hline Sectors & $1996-2001$ \\
\hline Agriculture, Foresting \& Fishing & .0118 \\
\hline Mining \& Quarrying & .0011 \\
\hline Manufacturing & .0037 \\
\hline Construction & .0017 \\
\hline Electricity, Gas \& Water Supply & .0006 \\
\hline Transport, Storage \& Communication & .0090 \\
\hline Wholesale and Retail Trade, Hotel and Restaurants & .0071 \\
\hline Financial Services, Real Estate and Business Services & .0051 \\
\hline Public Administration, Other Govt. Services and Defence & .0001 \\
\hline CV (\%) & $\mathbf{9 2 . 0 6}$ \\
\hline
\end{tabular}


Table 16: Estimation of the NAV for Sri Lanka

\begin{tabular}{|l|c|}
\hline Sectors & $\mathbf{2 0 0 2 - 2 0 1 3}$ \\
\hline Agriculture, Foresting & .0162 \\
\hline Fishing & .0012 \\
\hline Mining \& Quarrying & .0084 \\
\hline Manufacturing & .0067 \\
\hline Construction & .0126 \\
\hline Electricity, Gas \& Water Supply & .0014 \\
\hline Transport, Storage \& Communication & .0199 \\
\hline Wholesale and Retail Trade & .0057 \\
\hline Hotel and Restaurants & .0029 \\
\hline Banking, Insurance \& Real Estate & .0039 \\
\hline Ownership of Dwelling & .0088 \\
\hline Government Services & .0098 \\
\hline Private Services & .0005 \\
\hline CV (\%) & $\mathbf{7 9 . 1 4}$ \\
\hline
\end{tabular}

Source: Estimated from data given in Economic and Social Statistics of Sri Lanka 2014, Central Bank of Sri Lanka

Table 17: Estimation of the NAV for Nepal

\begin{tabular}{|l|c|c|}
\hline Sectors & $\mathbf{1 9 8 4 - 8 5}$ to $\mathbf{1 9 8 8 - 8 9}$ & $\mathbf{1 9 8 9 - 9 0}$ to 2004-05 \\
\hline Agriculture, Fisheries and Forestry & .0094 & .0464 \\
\hline Mining and Quarrying & .0003 & .0001 \\
\hline Manufacturing & .0009 & .0122 \\
\hline Electricity, Gas and Water & .0004 & .0061 \\
\hline Construction & .0069 & .0011 \\
\hline Trade, Restaurants \& Hotels & .0005 & .0017 \\
\hline Transport, Communications \& Storage & .0008 & .0137 \\
\hline Financial \& Real Estate & .0004 & .0045 \\
\hline Community \& Social Services & .0056 & .0105 \\
\hline CV (\%) & $\mathbf{1 2 5 . 5 6}$ & $\mathbf{1 3 3 . 4 4}$ \\
\hline
\end{tabular}


Table 18: Estimation of the NAV for Sri Lanka

\begin{tabular}{|l|c|}
\hline Sectors & 2005-06 to 2014-15 \\
\hline Agriculture and forestry & .0181 \\
\hline Fishing & .0003 \\
\hline Mining and Quarrying & .0003 \\
\hline Manufacturing & .0049 \\
\hline Electricity, Gas and Water & .0009 \\
\hline Construction & .0013 \\
\hline Wholesale and retail trade & .0018 \\
\hline Hotels and restaurants & .0009 \\
\hline Transport, storage and communications & .0109 \\
\hline Financial intermediation & .0003 \\
\hline Real estate, renting and business activities & .0015 \\
\hline Public Administration and defence & .0000 \\
\hline Education & .0053 \\
\hline Health and social work & .0015 \\
\hline Other community, social and personal service activities & .0071 \\
\hline CV (\%) & $\mathbf{1 3 7 . 6 3}$ \\
\hline
\end{tabular}

Source: Estimated from data given in Economic Survey 2014, Government of Nepal

Table 19: Regression Estimates

\begin{tabular}{|c|c|c|c|}
\hline Period & $\begin{aligned} \mathbf{Y} & =\mathbf{a}+\mathbf{b} \mathbf{X}_{\mathrm{t}-1} \\
\text { Where } \mathrm{Y} & =\mathrm{GDP} ; \mathrm{X}=\mathrm{NAV}\end{aligned}$ & $\begin{array}{c}\text { ' } \boldsymbol{t} \text { ' value } \\
\text { of } \mathrm{b} \text { coefficient }\end{array}$ & $\mathbf{R}^{2}$ \\
\hline \multicolumn{4}{|c|}{ INDIA } \\
\hline $1950-51$ to $1964-65$ & $Y=6.548-111.936 X$ & 1.857 & 0.239 \\
\hline $1965-66$ to $1978-79$ & $\mathrm{Y}=6.059-178.638 \mathrm{X}$ & 1.130 & 0.104 \\
\hline $1980-81$ to $1990-91$ & $Y=6.493-133.007 X$ & 1.046 & 0.090 \\
\hline $1991-92$ to $2003-04$ & $Y=5.071+6.746 X$ & 0.094 & 0.163 \\
\hline $2004-05$ to $2012-13$ & $Y=5.504+231.944 X$ & 1.464 & 0.163 \\
\hline \multicolumn{4}{|c|}{ SRI LANKA } \\
\hline 1970 to 1981 & $Y=5.950+100.649 X$ & 0.338 & 0.013 \\
\hline 1982 to 1995 & $Y=4.369+8.986 X$ & 0.158 & 0.003 \\
\hline 1996 to 2001 & $\mathrm{Y}=4.619-31.437 \mathrm{X}$ & 0.137 & 0.003 \\
\hline 2002 to 2013 & $Y=7.598-22.117 X$ & 0.110 & 0.001 \\
\hline \multicolumn{4}{|c|}{ NEPAL } \\
\hline $1984-85$ to $1988-89$ & $Y=6.204-28.108 X$ & 0.074 & 0.001 \\
\hline $1989-90$ to $2004-05$ & $Y=5.794-52.313 X$ & 0.984 & 0.122 \\
\hline $2005-06$ to $2013-14$ & $\mathrm{Y}=4.524+46.035 \mathrm{X}$ & 0.380 & 0.011 \\
\hline
\end{tabular}

Source: Estimated from data provided in Statistical Year Book 2014 of India; Economic and Social Statistics of Sri Lanka 2014, Central Bank of Sri Lanka; Economic Survey 2014 of Nepal 
Table 20: Regression Estimates

\begin{tabular}{|c|c|c|c|}
\hline Period & $\begin{aligned} \mathbf{Y} & =\mathbf{a}+\mathbf{b} \mathbf{X}_{\mathrm{t}-1} \\
\text { Where } \mathrm{Y} & =\mathrm{NAV} ; \mathrm{X}=\text { GDP }\end{aligned}$ & $\begin{array}{l}\text { ' } \boldsymbol{t} \text { ' value of } \\
\mathrm{b} \text { coefficient }\end{array}$ & $\mathbf{R}^{2}$ \\
\hline \multicolumn{4}{|c|}{ INDIA } \\
\hline $1950-51$ to $1964-65$ & $\mathrm{Y}=0.024-0.003 \mathrm{X}$ & 1.977 & 0.262 \\
\hline $1965-66$ to $1978-79$ & $\mathrm{Y}=0.011-0.001 \mathrm{X}$ & 0.864 & 0.064 \\
\hline $1980-81$ to $1990-91$ & $\mathrm{Y}=0.010-0.001 \mathrm{X}$ & 1.164 & 0.110 \\
\hline $1991-92$ to $2003-04$ & $\mathrm{Y}=0.007+9.825 \mathrm{X}$ & 0.087 & 0.001 \\
\hline $2004-05$ to $2012-13$ & $\mathrm{Y}=0.002+0.001 \mathrm{X}$ & 1.233 & 0.121 \\
\hline \multicolumn{4}{|c|}{ SRI LANKA } \\
\hline 1970 to 1981 & $\mathrm{Y}=0.007+9.985 \mathrm{X}$ & 0.223 & 0.005 \\
\hline 1982 to 1995 & $\mathrm{Y}=0.008+0.001 \mathrm{X}$ & 0.180 & 0.004 \\
\hline 1996 to 2001 & $Y=0.005-0.0001 X$ & 0.292 & 0.012 \\
\hline 2002 to 2013 & $\mathrm{Y}=0.008-3.616 \mathrm{X}$ & 0.072 & 0.001 \\
\hline \multicolumn{4}{|c|}{ NEPAL } \\
\hline $1984-85$ to $1988-89$ & $Y=0.001+0.0001 X$ & 0.823 & 0.088 \\
\hline $1989-90$ to $2004-05$ & $Y=0.024-0.003 X$ & 0.799 & 0.084 \\
\hline $2005-06$ to $2013-14$ & $Y=0.001+0.001 X$ & 0.612 & 0.028 \\
\hline
\end{tabular}

Source: Estimated from data provided in Statistical Year Book 2014 of India; Economic and Social Statistics of Sri Lanka 2014, Central Bank of Sri Lanka; Economic Survey 2014 of Nepal

Now, let us understand the relationship between the structural change as measured through the NAV and the GDP. These are estimated in tables $19 \& 20$. We may find that there has not been anywhere a significant relationships whether we take GDP as dependent variable and the NAV as the independent variable or the vice versa. However, Kortuk and Singh (2015) have been hilarious when they claim that such relationships might be accepted to hold even if they do not test statistically significant. This is true for all the three economies of India, Sri Lanka and Nepal that we have taken here for the study. Thus, our findings and inferences are not similar to the one by Kortuk and Singh (2015). We have not estimated any significant relationship between growth rate of any economy of India, Sri Lanka or Nepal and structural transformation there. It implies that growth rate and structural transformations do not boost each other. Rather, there could be some outside factors promoting these two variables in the respective economies and these needed to be identified by later studies.

\section{Concluding Remarks}

From the above analysis there are several factors that come to the fore for understanding the economic growth in South Asian nations particularly India, Nepal and Sri Lanka. We find with the long run analysis of the economic growth and structural transformations among these economies that there is improvement in growth across the nations but with varying degrees. As 
far as the growth rate is concerned, the Indian economy has made the fastest progress and that it is sustaining at very high rate for quite a long period. However, at the sectoral levels, the growth performance does not seem to get evenly spread both in terms of quantum as well as in terms of the acceleration test. Sri Lanka is another South Asian economy that is now joining the club of fast growing nations particularly since the preceding decade. Here, the sectoral growth trend is not very consistent too and all the sectors have not been performing at the desired and equal pace. Lowest position has been occupied by the Nepalese economy since its growth rate remains caged around 4 percent for the last more than three decades and there is relatively lower pace of structural transformations. However, what has been common to all the three countries is that there is stagnation or poor performance by the secondary sector while the tertiary sector has become the predominant sector. We find that there has been growth coupled with the structural transformation in all the three economies. But, when we test the hypothesis whether the GDP growth affects structural transformation or the vice versa, our analysis does not find any such relationships statistically significant in any of the economies. Still, economic growth takes place while showing accelerated growth and there has been structural transformation of varying degrees. Thus, we may infer that the growth and structural transformation in these economies have not been reinforced mainly by each other. Rather these changes are being caused by some other economic behavior. These need to be looked into with new insights to understand the real sources of economic growth or the points of blockades in the growth and structural transformations.

\section{References}

Agarwal, M K (2013). Emergence of the Economies of India and Sri Lanka in M. K. Agarwal (ed.). Issues in India-Sri Lanka Economies, Northern Book Center, New Delhi.

Agarwal, Manoj Kumar and Upadhyay, R.P. (2006). Tourism and Economic Development in Nepal. Northern Book Center, New Delhi.

Balakrishanan, Punlapre and M. Parameshwaran (2007). Understanding economic growth in India. Economic and Political Weekly, 42(27-28): 2915-2922.

Central Bank of Sri Lanka (2015). Economic and Social Statistics of Sri Lanka 2014, Central Bank of Sri Lanka, Colombo.

Chenery H. and Taylor, L. (1968). Development patterns: Among countries and over time. Review of Economics and Statistics, November.

Clark, Colin (1940): The Conditions of Economic Progress. Macmillan, London.

Coutuk, Orcan and Nirvikar Singh(2015). Analysing the structural change and growth relationship in India. Economic and Political Weekly, L(24): 91-98.

Desai, V. Ashok (1966). Growth and cycles in the Indian economy 1951-1964. Economic and Political Weekly, 1(14): 591-594.

Devarajan, Shantayanan and Ijaz Nabi (2006). Economic growth in South Asia: Promising, unequalising, sustainable?. Economic and Political Weekly, 41(33): 3573-3580.

Dholakia, Ravindra H. (1994). Spatial dimension of acceleration of economic growth in India. Economic and Political Weekly, 29 (25): pp 230-2309. 
Government of India (2014). Economic Survey 2013-14, Oxford University Press, New Delhi.

Government of India (2014). Statistical Year Book, India 2014, Ministry of Statistics and Programme Implementation, New Delhi.

Government of India (2016). Economic Survey 2015-16; Young Global Publications, New Delhi.

Government of India (2016). Statistical Year Book, India 2016, Ministry of Statistics and Programme Implementation, New Delhi.

Government of Nepal (2005). Economic Survey 2005, Ministry of Finance, Kathmandu.

Government of Nepal (2014). Economic Survey 2014, Ministry of Finance, Kathmandu.

Herath, H M S P (2011). Impact of trde liberalization on economic growth of Sri Lanka: An econometric investigation' http:/www.kln.ac.lk/fcms/ICBI2011/images/ICBM/dccs/ Microsoft $\% 20$ Word\%20-\%20ECN006.pdf.

Herath, H M S P (2016). The casual relationship between trade and economic growth in Sri Lanka. Wayamba Journal of Management, 4(2): 30-40.

Hirschman, A. (1958). Strategy of Economic Development; Yale University Press, New Haven, USA.

Kaldor, Nicholas (1957). A Model of Economic Growth. Economic Journal, 67:

Kaur, Paramjeet (2007). Growth Acceleration in India. Economic and Political Weekly, 42(15): 1380-1386.

Lewis, W Arthur (1954). Economic development with unlimited supplies of labour. The Manchester School, 22(2): 139-191.

Nagaraj, R. (2003). Industrial policy and performance since 1980: Which Way Now?. Economic and Political Weekly, 38(35): 3707-3715.

Naidu, Y. G. (2006). Globalization and its impact on Indian society. Indian Journal of Political Sciences, 67(1): 65-76.

Naseem, S. M. and Zahid Zaheer (2005). Economic growth and development in South Asia,with and without regional cooperation. The Pakistan Development Review, 43(4): 397-422.

Nayyar, Deepak (2006). Economic growth in independent India: Lumbering elephant or running tiger?. Economic and Political Weekly, 41(51): 145-58.

Parikh Kirit S. (2006). Explaining growth in South Asia. Oxford University Press, New Delhi.

Ranis, Gustav and John, C.H. Fei (1961). A theory of economic development. American Economic Review, 51(4): 535-565.

Rostow, W.W. (1960). The Stages of Economic Growth. Cambridge University Press, Cambridge. 
62 Agarwal \& Ritika: Growth and Structural Changes in the South Asian Economies of India, Nepal and ...

Sastry, D.V.S., Singh,B., Bhattacharya, K. and Unnikrishnan, N. K. (2003). Sectoral linkages and growth prospects: reflections on the Indian economy. Economic and Political Weekly, 38(24): 2390-2397.

Shah, Sukhdev (1981). Developing an economy- Nepal's experience. Asian Survey, 21(10): 1060-1079.

United Nation (2006). Diverging growth and development. World Economic and Social Survey. New York, United Nations Department of Economic and Social Affairs.

Wallack, J.S. (2003). Structural breaks in Indian economic macroeconomic data. Economic and Political Weekly, 38(41): 4312-4315. 